https://doi.org/10.48009/1_iis_2009_28-39

\title{
A COMPARISON OF STUDY ABROAD AND GLOBALIZATION ATTITUDES AMONG INFORMATION SYSTEMS, COMPUTER SCIENCE, AND BUSINESS STUDENTS: RECOMMENDATIONS FOR IS CURRICULUM DESIGN
}

\author{
Peter W. Cardon, University of South Carolina, pcardon@sc.edu \\ Bryan A. Marshall, Georgia College \& State University, bryan.marshall@gcsu.edu \\ Nipul Patel, Purdue University North Central, npatel@pnc.edu \\ Natalya Goreva, Point Park University, natalya.goreva@gmail.com \\ Renée J. Fontenot, Georgia College \& State University, renee.fontenot@gcsu.edu
}

\begin{abstract}
The objectives of this study were to identify IS students' (1) study abroad desires, (2) study abroad beliefs, (3) study abroad preferences, (4) globalization beliefs, and (5) the factors that predict study abroad desires, and provide IS educators with recommendations for increasing student participation in study abroad programs. A survey was conducted of a sample of 339 IS, business, and CS majors. Most IS and business students express strong interest in studying abroad. In a regression analysis, study abroad career beliefs and major were significant predictors of desire to study abroad. Upper class majors approached significance in being less likely to desire studying abroad, and upper income students approached significance in being more likely to desire studying abroad. Globalization beliefs and gender were not significant predictors of desire to study abroad. Major conclusions include the following: (1) IS majors' study abroad destination choices are not strategic; (2) IS majors report that parents have more influence on their study abroad decisions than friends, instructors, and advisors; (3) IS majors express strong agreement that studying abroad and working effectively with members of other cultures is important to their careers; and (4) beliefs about the impact of globalization on the economy and gender are not predictors of desire to study abroad. The conclusion resulted in 15 recommendations for IS educators.
\end{abstract}

Keywords: study abroad, globalization, IS curriculum, internationalization, international IS

\section{INTRODUCTION}

In a 2000 American Council on Education [ACE] survey of college-bound American students, $50 \%$ of students stated that they wanted to study abroad. Ultimately, only $5 \%$ of them did, which has been labeled as a "frustrated ideal" (p. 1) [2]. In the most recent round of this survey in 2007, $81 \%$ of

Volume X, No. 1, 2009 respondents stated that they wanted to study abroad, and $55 \%$ were certain or fairly certain that they would study abroad. The authors of the study stated that their survey research demonstrated the following:

The interest of college-bound students in international learning experiences is extraordinarily high. The nature of the international experiences they seek is expansive, including not only study abroad, but also internships, cultural immersions, and fluency in a foreign language. [2] (p. 1)

The purpose of this study was to identify IS students' study abroad interest levels and study abroad preferences and provided recommendations for IS educators. The study explored the degree to which study abroad beliefs, globalization attitudes, and selected demographic variables influenced their study abroad desires. This includes comparisons with business and computer science students (rationale for doing so is provided in the Research Methodology section). From the study, data-driven recommendations for IS curriculum and practice are given to help others avoid IS students' study abroad desires and IS educators' internationalization efforts from becoming frustrated ideals.

\section{LITERATURE REVIEW}

American universities are increasingly focusing on internationalization efforts. One of the primary ways with which universities encourage internationalization is through study abroad. In the 2006-2007 academic year among Americans who studied abroad, $57 \%$ went to Europe, followed by $15 \%$ to Latin America, $10 \%$ to Asia, $6 \%$ to Oceania (including Australia), $4 \%$ to Africa, and $1 \%$ to the Middle East. Among countries, the top ten destinations were the United Kingdom (32,705 students), Italy (27,831), Spain (24,005), France $(17,233)$, China $(11,064)$, Australia $(10,747)$, Mexico
Issues in Information Systems 
$(9,461)$, Germany $(7,355)$, Ireland $(5,785)$, and Costa Rica $(5,383)$. Business and management students comprised $17 \%(46,061)$ of all American students studying abroad. Computer science/math majors comprised just $1.5 \%(3,587)[5]$.

Business schools in particular have focused on internationalization for decades, and internationalization of the curriculum has been an integral part of AACSB accreditation during this entire period [13]. One indicator of the emphasis on internationalization in recent years is the required reading in many business colleges of The World is Flat by Thomas Friedman [8]. Furthermore, IS and CS curriculum standards increasingly recognize the importance of developing international competencies.

Recent IS curriculum standards explicitly state the importance of international skills. The IS 2002 Curriculum states the following:

They [IS students] should have a basic understanding of the main functional areas of an organization and should have been exposed to concepts of international business. Some of the topics should be prerequisites but others may be interleaved with Information Systems courses. [9] (p. 12)

Standard 9.3.2 of The IS 2002 Curriculum is devoted to Modeling Local and International Work Environments. In this section, the following statement summarizes the importance of developing international/intercultural skills: "Faculty can discuss and have students apply international, intercultural, and workplace issues within the context of computing resources, teamwork, and projects" [9] (p. 35). Furthermore, a number of learning outcomes specifically address issues related to globalization, such as the following: "Describe how IT has impacted the globalization of world economy, culture, political systems, health, security, warfare, etc." [9] (p. 59).

Similarly, Computing Curriculum 2005 recommends that students have an understanding of international issues: "Recent efforts have targeted international participation, reflecting the need for the leading professional organizations to become truly global in scope and responsibility" [11] (p. 7).

Many IS educators believe that the vast majority of IS majors, even if they never work abroad, will need to work effectively across cultures since they will work with colleagues or clients of other cultural backgrounds who may reside in many countries [13]. Although most IS educators recognize the importance of developing international competencies, there is little room for adding courses to an already crammed IS curriculum. One IS educator describes the dilemma in this way:

The importance of internationalizing the curriculum is widely recognized among business school faculty and administrators, but there is a major problem for curriculum designers and for professors who wish to include international material in their courses: Where do you put it? How do you squeeze it into a curriculum that is already bursting at the seams? How do you justify adding this international material rather than other important topics? How do you decide what to cut to make room for it? [13] ( p. 194)

According to this IS educator, IS curriculums should emphasize incorporating international competencies into existing courses rather than stand-alone international courses. The following competencies in an international context should be incorporated into the IS curriculum: time zone differences; language differences; cultural differences; project management; training differences; database requirements; system factors; technology transfer; and locality differences [13].

One benefit of developing international competencies is the focus on developing soft skills. Research has consistently demonstrated the importance of soft skills for information technology personnel, including team work, inter-team communication, interpersonal skills, constructive criticism, leadership, presentation skills, and working across cultures $[3,4,12]$. Offshoring of technology jobs accentuates the need to have soft skills and business savvy among IS students:

Many of our graduates will be involved as the onshore project coordinators either working for the U.S. company or as the onshore workforce for foreign outsourcing companies. Therefore, communication skills will be a premium. CTO's found poor communication to be the most common reason work sent offshore failed to meet project specifications. Teaching students to write detailed, unambiguous, requirement specification has always been a challenge. Now we must consider cultural nuances, non face-to-face communication, language familiarity, and other such issues. [7] (p. 73) 
One of the primary ways with which IS students can gain international competencies is through study abroad programs. Yet, for all of the dialogue about internationalizing business schools and IS programs, no concrete research about study abroad for IS majors was found. Thus, this study is particularly warranted to begin a research-based conversation about how study abroad can meet the needs of IS students.

\section{RESEARCH METHODOLOGY}

The study was oriented towards IS students primarily because the authors teach in IS programs and are concerned with preparing IS students to thrive in a globalized work environment. However, comparisons with business and computer science/engineering students were included for several reasons. First, a variety of IS courses service business and computer science students. In many cases, there are more business students than IS students in any particular IS course. Second, a simplified view of the IS major is that it combines aspects of business and CS majors. In other words, in brings the two fields together.

The survey included 339 IS, business, and CS majors. In the CS majors group, some engineering students were incorporate (primarily electrical and computer engineering students) (see Table 1 for demographics information). The survey was administered at several schools and the results combined.

Table 1. Demographics of Survey Respondents

\begin{tabular}{lrr}
\hline & $n$ & $\%$ \\
\hline Gender & & \\
Male & 227 & 66.8 \\
Female & 112 & 32.9 \\
Ethnicity & & \\
African American & 29 & 8.5 \\
Asian American & 8 & 2.4 \\
Hispanic American & 15 & 4.4 \\
European American & 265 & 77.9 \\
Other & 23 & 6.8 \\
School Year & & \\
Freshman & 60 & 17.6 \\
Sophomore & 60 & 17.6 \\
Junior & 116 & 34.1 \\
Senior & 82 & 24.1 \\
Graduate & 21 & 6.2 \\
Income & &
\end{tabular}

Volume X, No. 1, 2009

\begin{tabular}{lrr} 
Low Income & 27 & 7.9 \\
Lower Middle Income & 124 & 36.5 \\
Upper Middle Income & 175 & 51.5 \\
High Income & 12 & 3.5 \\
\hline
\end{tabular}

The survey included the following components: (1) background (demographics) information; (2) prior international travel experience; (3) study abroad desires; (4) study abroad attitudes and beliefs; (5) study abroad preferences; (6) importance of influential others on decision-making; and (7) globalization attitudes and beliefs (see Appendix of Survey Items). Survey items were based on a prior study of study abroad [6].

Table 2. Prior International of Survey Respondents

\begin{tabular}{lrr}
\hline \multicolumn{1}{l}{$\begin{array}{r}\text { Studied Abroad } \\
\text { Yes }\end{array}$} & & \\
$\begin{array}{l}\text { International Travel } \\
\text { Yes }\end{array}$ & 23 & 6.8 \\
Times Travelled Internationally & & \\
\hline 0 & & \\
1 & 106 & 31.2 \\
2 & 81 & 23.8 \\
3 & 47 & 13.8 \\
4 & 29 & 8.5 \\
5 or more & 16 & 4.7 \\
Prior Travel Destinations & 57 & 16.8 \\
Caribbean & & \\
Mexico & 108 & 31.8 \\
Canada & 108 & 31.8 \\
Latin America & 106 & 31.2 \\
(excluding Mexico) & 17 & 5.0 \\
Europe & 97 & 28.5 \\
Asia & 19 & 5.6 \\
Middle East & 10 & 2.9 \\
Australia/New Zealand & 10 & 2.9 \\
Other & 24 & 7.1 \\
\hline
\end{tabular}

In the study, students chose countries where they wanted to study abroad. These countries were grouped into the following regions: Western Europe, Other Europe, Australia/New Zealand, Asia, Latin America, Caribbean, Africa, Oceania, and Americas. For the most part, these classifications follow conventions of the United Nations (UN) with several

\section{Issues in Information Systems}


exceptions. First, Australia and Oceania are one geographic region in the UN classification. This region was divided into Australia/New Zealand and Oceania because Australia and New Zealand are strong preferences for study abroad, whereas the remaining Oceania locations are not. Further, they reflect a vastly different study abroad environment in terms of cultural differences and tourism infrastructure. Second, Europe was divided into two regions: Western Europe and Other Europe. In Western Europe, the UN subregions of Western Europe, Southern Europe, and the country of the United Kingdom were combined. The countries as classified this way reflect many common groupings of Western Europe, include the most common tourist and study abroad destinations in Europe, and include countries with common cultural and political heritage with the United States.

\section{FINDINGS}

IS majors expressed strong interest in studying abroad (see Table 3). Nearly half of respondents in the sample $(48.5 \%)$ agreed that they wanted to study abroad. Similarly, other business majors also express strong interest in studying abroad (45.3\%). IS and business majors were significantly more likely to express interest in studying abroad than CS majors $(26.2 \%)$.

In terms of countries where students want to study abroad (see Table 4), IS students chose Japan as a first choice (15.6\%) as well as a number of European nations and Australia. Business and CS students also chose primarily European nations and Australia. When broken down by region (see Table 5), these choices overwhelming are located in Western/Southern Europe for IS, business, and CS majors.

As far as countries that students perceived as their industries preferring for study abroad experience, China (see Table 4), Japan, India, and Germany were considered strong preferences. By region (see Table 5), Asia was overwhelmingly perceived as the most important location, particularly for IS and CS majors. In fact, approximately four-fifths $(79.5 \%)$ of IS majors in the sample perceived Asia as the industry choice for study abroad.

When asked about how influential others were on their study abroad decisions (see Table 6), business students were more likely to be influenced by parents and friends than CS majors. Generally, parents are considered more influential than friends, instructors, and advisors for IS, business, and CS majors. In the case of IS majors, approximately half of respondents $(46.4 \%)$ agreed that parents were influential in their decisions to study abroad compared to just one quarter to one third who stated that friends $(25.8 \%)$, instructors $(36.1 \%)$, or advisors $(32.0 \%)$ would be important in their decision-making.

When asked about an appropriate price for a 2-3 week study abroad excursion (see Table 7), between 36 and 45 percent of respondents expect programs to cost less than $\$ 1,500$, and between 60 and $70 \%$ expect programs to cost less than $\$ 2,000$. IS majors' expectations closely resemble those of business majors with the majority of respondents (60-62\%) expecting programs to cost between $\$ 1,000$ and $\$ 2,000$.

Three questions were used to gauge beliefs about how study abroad experience could impact jobs and careers (see Table 8). IS and business majors expressed stronger agreement than CS majors that study abroad would positively affect their careers. There was strong agreement among each of the majors that it is important to be able to work with members of other cultures.

Six questions were used to identify beliefs about the impact of globalization on the domestic economy and students' careers (see Table 9). Generally, each of the majors showed strong positive attitudes for globalization. Across majors, only one item, for one major, did not have a majority respond with a positive attitude for the impact of globalization: just under half of CS majors (47\%) believed that globalization was good for creating jobs in the United States. For questions about the impact of globalization on their own jobs and careers, between 61 and $82 \%$ of respondents felt globalization had a positive impact. Overall, IS and business majors were significantly more positive than CS majors about the influence of globalization on the domestic economy.

Finally, a regression analysis was conducted with the two-item desire to study abroad measure $(\alpha=837)$ as the dependent variable (see Table 10). Included as independent variables were: study abroad career beliefs (three-item measure; $\alpha=.826$ ), globalization career beliefs (six-item measure; $\alpha=.850$ ), gender (dummy coded for males), income (dummy coded for lower income), major (dummy coded for IS majors), and class (dummy coded for underclass students). Income was divided into two groups: a lower income group (combined categories of low income and lower middle income) and a higher income group (combined categories of upper middle income and 
A Comparison of Study Abroad and Globalization Attitudes among Information Systems, Computer Science, and business Students: Recommendations for IS Curriculum Design

high income). Class was divided into underclass (freshman and sophomores), upper class (juniors and seniors), and graduate students. 
A Comparison of Study Abroad and Globalization Attitudes among Information Systems, Computer Science, and Business Students: Recommendations for IS Curriculum Design

Table 3. Desire to Study Abroad

\begin{tabular}{|c|c|c|c|c|c|c|c|c|c|c|c|}
\hline & \multicolumn{3}{|c|}{ Business } & \multicolumn{3}{|c|}{$\mathrm{CS}$} & \multicolumn{3}{|c|}{$\underline{\mathrm{IS}}$} & \multirow[b]{3}{*}{$F$} & \multirow[b]{3}{*}{$p$} \\
\hline & & & $\%$ & & & $\%$ & & & $\%$ & & \\
\hline & $M$ & $S D$ & Agree & $M$ & $S D$ & Agree & $M$ & $S D$ & Agree & & \\
\hline $\begin{array}{l}\text { I want to study abroad } \\
\text { while I am a } \\
\text { university student. }\end{array}$ & 4.18 & 1.98 & 45.3 & $3.54_{c}$ & 1.97 & 26.2 & $4.53_{b}$ & 1.90 & 48.5 & 4.75 & $.01 * *$ \\
\hline $\begin{array}{l}\text { I will be disappointed } \\
\text { if I do not study } \\
\text { abroad before } \\
\text { completing my } \\
\text { degree. }\end{array}$ & 3.31 & 1.89 & 22.2 & 2.75 & 1.78 & 13.1 & 3.41 & 1.94 & 25.8 & 2.56 & .08 \\
\hline $\begin{array}{l}\text { Note. }{ }^{*} p<.05 ; * * p<.01 . \\
\text { Likert scale: } 5-7 . \text { An } a \text { s } \\
\text { indicates a mean signific } \\
\text { from IS majors on Tuke }\end{array}$ & $\begin{array}{l}\text { Agre } \\
\text { scrip } \\
\text { atly d } \\
\text { post }\end{array}$ & $\begin{array}{l}\text { efers } \\
\text { dica } \\
\text { erent }\end{array}$ & $\begin{array}{l}\text { the pe } \\
\text { a mea }\end{array}$ & $\begin{array}{l}\text { ntage } \\
\text { ignifi } \\
\text { jors, }\end{array}$ & esp & $\begin{array}{l}\text { lents } \mathrm{w} \\
\text { erent } \mathrm{fl}_{1}\end{array}$ & $\begin{array}{l}\exp \\
\mathrm{n} \mathrm{Bu}\end{array}$ & $\begin{array}{l}\text { sed } \\
\text { ess }\end{array}$ & $\begin{array}{l}\text { reemen } \\
\text { jors, a } \\
\text { a signif }\end{array}$ & $\begin{array}{l}\text { ubser } \\
\text { ubser } \\
\text { ntly o }\end{array}$ & $\begin{array}{l}\text { pt } \\
\text { ferent }\end{array}$ \\
\hline
\end{tabular}

Table 4. Study Abroad Preferences and Perceived Industry Choices by Country

\begin{tabular}{|c|c|c|c|c|c|c|c|c|c|c|c|}
\hline \multirow{2}{*}{\multicolumn{2}{|c|}{ Business }} & \multicolumn{4}{|c|}{ Preferences (\%/\#) } & \multicolumn{6}{|c|}{ Perceived Industry Choices (\%/\#) } \\
\hline & & \multicolumn{2}{|c|}{ CS/Eng } & \multicolumn{2}{|r|}{$\underline{I S}$} & \multicolumn{2}{|c|}{ Business } & \multicolumn{2}{|c|}{ CS/Eng } & \multicolumn{2}{|c|}{$\underline{I S}$} \\
\hline$A U$ & $19.2(33)$ & $D E$ & $22.0(13)$ & $J P$ & $15.6(15)$ & $\mathrm{CH}$ & $24.2(31)$ & $J P$ & $36.7(11)$ & $J P$ & $\overline{36} .1(30)$ \\
\hline$I T$ & $11.6(20)$ & $A U$ & $13.6(8)$ & $U K$ & $13.5(13)$ & $J P$ & $10.9(14)$ & $D E$ & $26.7(8)$ & $\mathrm{CH}$ & $18.1(15)$ \\
\hline$U K$ & $7.6(13)$ & $I T$ & $11.9(7)$ & $G R$ & $9.4(9)$ & $U K$ & $9.4(12)$ & $\mathrm{CH}$ & $20.0(6)$ & $I N$ & $18.1(15)$ \\
\hline$I R$ & $7.6(13)$ & $U K$ & $8.5(5)$ & $F R$ & $8.3(8)$ & $M X$ & $8.6(11)$ & $I N$ & $6.7(2)$ & $U K$ & $6.0(5)$ \\
\hline$D E$ & $7.0(12)$ & $F R$ & $6.8(4)$ & $A U$ & $7.3(7)$ & $F R$ & $7.0(9)$ & & & & \\
\hline & & $J P$ & $6.8(4)$ & $I T$ & $7.3(7)$ & & & & & & \\
\hline & & $B H$ & $6.8(4)$ & & & & & & & & \\
\hline
\end{tabular}

Note. $\mathrm{AU}=$ Australia, $\mathrm{BH}=$ Bahamas, $\mathrm{CH}=$ China, $\mathrm{DE}=$ Germany, FR $=$ France, $\mathrm{IN}=\mathrm{India}$, IR $=$ Ireland, IT $=$ Italy, JP = Japan, MX = Mexico, UK = United Kingdom. All choices are represented that comprised more than $5 \%$ of the total selections.

Table 5. Study Abroad Preferences and Perceived Industry Choices by Region

\begin{tabular}{|c|c|c|c|c|c|c|}
\hline & \multicolumn{3}{|c|}{$\underline{\text { Preferences }(\% / \#)}$} & \multicolumn{3}{|c|}{$\underline{\text { Perceived Industry Choices }(\% / \#)}$} \\
\hline & $\underline{\text { Bus }}$ & $\underline{\mathrm{CS}}$ & $\underline{I S}$ & $\underline{\text { Bus }}$ & $\underline{\mathrm{CS}}$ & $\underline{I S}$ \\
\hline Africa & $2.3(4)$ & $1.7(1)$ & $2.1(2)$ & $3.1(4)$ & $0.0(0)$ & $1.2(1)$ \\
\hline Americas & $0.0(0)$ & $0.0(0)$ & $0.0(0)$ & $.8(1)$ & $0.0(0)$ & $2.4(2)$ \\
\hline Asia & $7.0(12)$ & $6.7(4)$ & $20.8(20)$ & $45.3(58)$ & $63.3(19)$ & $79.5(66)$ \\
\hline Australia/Oceania & $21.5(37)$ & $20.0(12)$ & $9.4(9)$ & $6.2(8)$ & $3.3(1)$ & $4.8(4)$ \\
\hline Caribbean & $4.7(8)$ & $6.7(4)$ & $4.2(4)$ & $3.1(4)$ & $0.0(0)$ & $1.2(1)$ \\
\hline Latin America & $9.3(16)$ & $5.0(3)$ & $6.2(6)$ & $10.9(14)$ & $0.0(0)$ & $0.0(0)$ \\
\hline Other Europe & $1.7(3)$ & $0.0(0)$ & $4.2(4)$ & $0.0(0)$ & $0.0(0)$ & $3.6(3)$ \\
\hline Western/Southern Europe & $53.5(92)$ & $60.0(36)$ & $53.1(51)$ & $28.9(37)$ & $33.3(9)$ & $10.8(9)$ \\
\hline
\end{tabular}

Note. ${ }^{*} p<.05 ; * * p<.01 . \%$ Agree refers to the percentage of respondents who expressed agreement on the 7-pt Likert scale: 5-7. An $a$ subscript indicates a mean significantly different from Business majors, a $b$ subscript indicates a mean significantly different from CS majors, and a $c$ subscript indicates a mean significantly different from IS majors on Tukey's post-hoc test at $p<.05$. Cronbach's alpha $=.826$ for 3 items. 
A Comparison of Study Abroad and Globalization Attitudes among Information Systems, Computer Science, and business Students: Recommendations for IS Curriculum Design

Table 6. Attitudes about Importance of Influential Others on Decision to Study Abroad

\begin{tabular}{lccccccccccc}
\hline & \multicolumn{3}{c}{ Business } & \multicolumn{3}{c}{ CS } & \multicolumn{3}{c}{$\underline{\text { IS }}$} & & \\
& $M$ & $S D$ & Agree & $M$ & $S D$ & Agree & $M$ & $S D$ & Agree & $F$ & $p$ \\
\hline Parents & $4.58_{\mathrm{b}}$ & 1.94 & 58.8 & $3.75_{\mathrm{a}}$ & 1.79 & 36.7 & 4.13 & 1.86 & 46.4 & 4.83 & $.01^{* *}$ \\
Friends & $3.83_{\mathrm{b}}$ & 1.58 & 34.3 & $3.13_{\mathrm{a}}$ & 1.55 & 19.7 & 3.45 & 1.65 & 25.8 & 4.76 & $.01 * *$ \\
Instructors & 3.99 & 1.55 & 38.2 & 3.52 & 1.52 & 24.6 & 3.97 & 1.59 & 36.1 & 2.18 & .12 \\
Advisor & 3.96 & 1.69 & 38.8 & 3.49 & 1.57 & 24.6 & 3.80 & 1.60 & 32.0 & 1.84 & .16 \\
\hline
\end{tabular}

Note. $* p<.05 ; * * p<.01 . \%$ Agree refers to the percentage of respondents who expressed agreement on the 7 -pt Likert scale: 5-7. An $a$ subscript indicates a mean significantly different from Business majors, a $b$ subscript indicates a mean significantly different from CS majors, and a $c$ subscript indicates a mean significantly different from IS majors on Tukey's post-hoc test at $p<.05$. Cronbach's alpha $=.826$ for 3 items.

Table 7. Appropriate Price for a 2-3 Week Study Abroad Excursion

\begin{tabular}{lccc}
\hline & Bus & $\underline{\text { CS/Eng }}$ & $\underline{\text { IS }}$ \\
\hline Under $\$ 1,000$ & $10.0 \%(17)$ & $25.9 \%(15)$ & $13.4 \%(13)$ \\
$\$ 1,000-\$ 1,500$ & $25.9 \%(44)$ & $19.0 \%(11)$ & $25.8 \%(25)$ \\
$\$ 1,500-\$ 2,000$ & $34.1 \%(58)$ & $34.5 \%(20)$ & $36.1 \%(35)$ \\
$\$ 2,000-\$ 3,000$ & $20.0 \%(34)$ & $12.1 \%(7)$ & $17.5 \%(17)$ \\
$\$ 3,000-\$ 4,000$ & $8.2 \%(14)$ & $5.2 \%(3)$ & $5.2 \%(5)$ \\
Over $\$ 4,000$ & $1.8 \%(3)$ & $3.4 \%(2)$ & $2.1 \%(2)$ \\
\hline
\end{tabular}

Table 8. Beliefs about Study Abroad and Careers

\begin{tabular}{|c|c|c|c|c|c|c|c|c|c|c|c|}
\hline & \multicolumn{3}{|c|}{ Business } & \multicolumn{3}{|c|}{$\underline{\mathrm{CS}}$} & \multicolumn{2}{|r|}{$\underline{I S}$} & \multirow[b]{2}{*}{$\%$} & \multirow[b]{2}{*}{$F$} & \multirow[b]{2}{*}{$p$} \\
\hline & $M$ & $S D$ & $\begin{array}{c}\% \\
\text { Agree }\end{array}$ & $M$ & $S D$ & $\begin{array}{c}\% \\
\text { Agree }\end{array}$ & $M$ & $S D$ & & & \\
\hline $\begin{array}{l}\text { Studying abroad } \\
\text { will help me get a } \\
\text { job. }\end{array}$ & 4.22 & 1.68 & 44.7 & 3.77 & 1.70 & 34.4 & 3.96 & 1.64 & 33.7 & 1.85 & .16 \\
\hline $\begin{array}{l}\text { Studying abroad } \\
\text { will be helpful for } \\
\text { my career. }\end{array}$ & $4.70_{\mathrm{b}}$ & 1.57 & 60.1 & $3.93_{\mathrm{a}, \mathrm{c}}$ & 1.77 & 36.6 & $4.71_{b}$ & 1.71 & 60.6 & 5.36 & $.01^{* *}$ \\
\hline $\begin{array}{l}\text { It is important for } \\
\text { people in my } \\
\text { (future) industry to } \\
\text { be able to work } \\
\text { with members of } \\
\text { other cultures. }\end{array}$ & 5.42 & 1.72 & 74.9 & $5.10_{\mathrm{c}}$ & 1.74 & 67.2 & $5.79^{\mathrm{b}}$ & 1.51 & 78.3 & 3.45 & $.03^{*}$ \\
\hline Overall & $4.78_{b}$ & 1.46 & & $4.26_{\mathrm{a}, \mathrm{c}}$ & 1.45 & & $4.83_{b}$ & 1.36 & & 3.53 & $.03^{*}$ \\
\hline
\end{tabular}

Note. $* p<.05 ; * * p<.01 . \%$ Agree refers to the percentage of respondents who expressed agreement on the 7-pt Likert scale: 5-7. An $a$ subscript indicates a mean significantly different from Business majors, a $b$ subscript indicates a mean significantly different from CS majors, and a $c$ subscript indicates a mean significantly different from IS majors on Tukey's post-hoc test at $p<.05$. Cronbach's alpha $=.826$ for 3 items. 
Table 9. Attitudes about Impact of Globalization on Domestic Economy

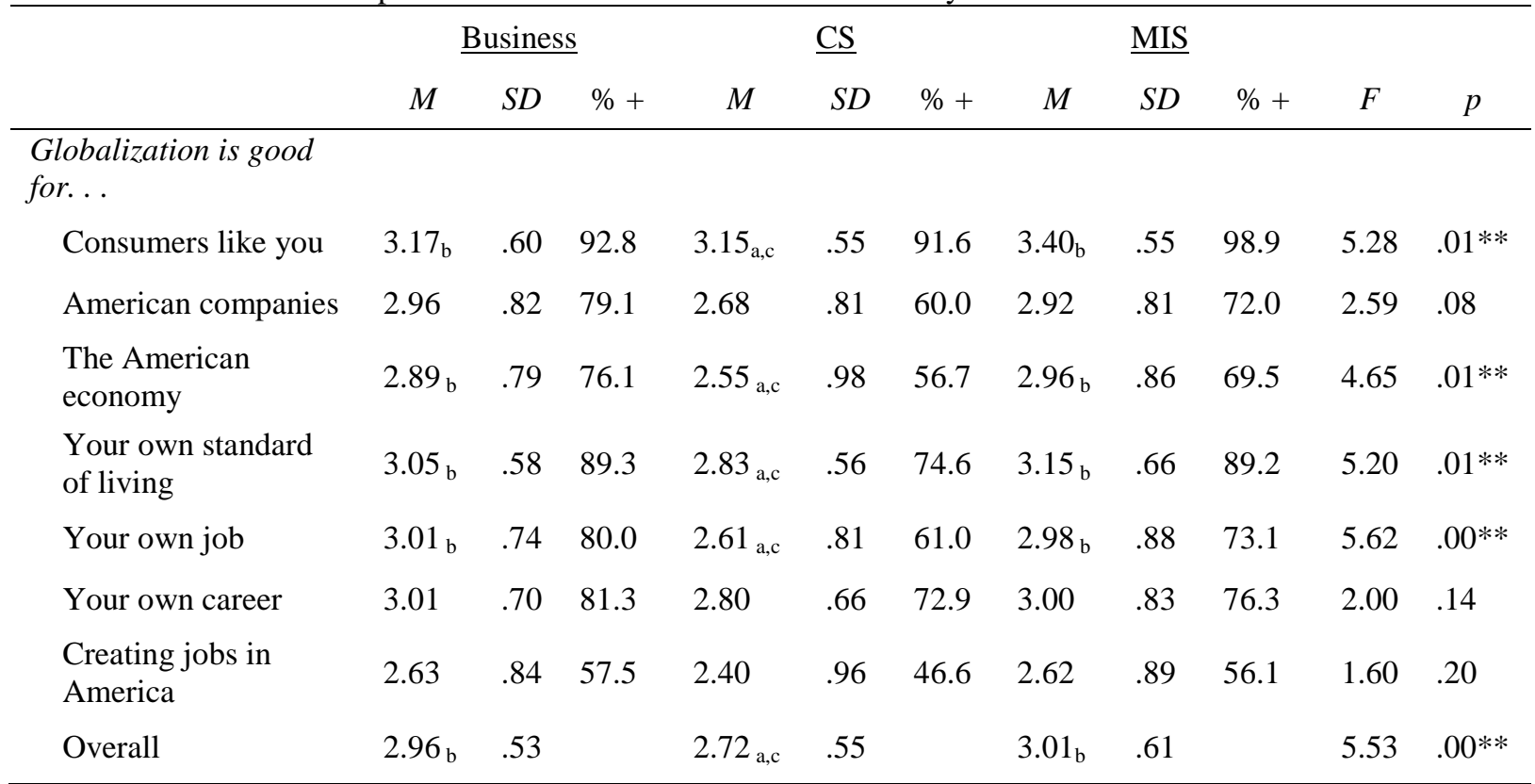

Note. $* p<.05 ; * * p<.01 . \%+$ refers to the percentage of respondents who expressed a positive attitude for each item: good (3) or extremely good (4). An $a$ subscript indicates a mean significantly different from Business majors, a $b$ subscript indicates a mean significantly different from CS majors, and a $c$ subscript indicates a mean significantly different from MIS majors on Tukey's post-hoc test at $p<.05$. Cronbach's alpha $=.850$ for the 6 items.

Table 10. Regression of Desire to Study Abroad

\begin{tabular}{lccccc}
\hline & \multicolumn{2}{c}{ Unstandardized } & & \multicolumn{2}{c}{ Standardized } \\
& \multicolumn{2}{c}{ Coefficients } & & \multicolumn{2}{c}{ Coefficients } \\
& $B$ & $S E$ & $B$ & $t$ & $p$ \\
\hline Constant) & .71 & .53 & & 1.36 & .17 \\
Study abroad career beliefs & .68 & .06 & .54 & 1.64 & $.00^{* *}$ \\
Globalization career beliefs & -.01 & .15 & .00 & -.03 & .98 \\
Gender (males) & & & & & \\
$\quad$ Females & .03 & .19 & .01 & .17 & .87 \\
Income (lower) & & & & & \\
$\quad$ Upper income & .33 & .18 & .09 & 1.88 & .06 \\
Major (IS) & & & & & \\
$\quad$ CS & -.56 & .28 & -.12 & -2.04 & $.04 *$ \\
$\quad$ Bus & -.19 & .21 & -.05 & -.89 & .37 \\
Class (underclass) & & & & & \\
$\quad$ Upper class & -.35 & .19 & -.10 & -1.87 & .06 \\
$\quad$ Graduate & .14 & .42 & .02 & .33 & .75 \\
\hline
\end{tabular}

Note. ${ }^{*} p<.05 ; * * p<.01$. Regression model $R^{2}=.32(p=.00 * *)$. Variables in parentheses are baseline measures for dummy coded variables. 
The most significant factor $(p=.00)$ with the strongest beta in the regression analysis was study abroad career beliefs. CS majors were significantly less likely to desire studying abroad ( $p=.04)$, upper class majors approached significance in being less likely to desire studying abroad $(p=.06)$, and upper income students approached significance in being more likely to desire studying abroad $(p=.06)$.

\section{CONCLUSIONS \& RECOMMENDATIONS}

Approximately half of IS students want to study abroad. The enormous demand for study abroad among IS students is in of itself a reason for IS educators to get involved in IS students' decisionmaking process to study abroad. Therefore, the following recommendations are proffered:

1. IS educators should formulate policies for how IS students should be rewarded for study abroad programs.

2. IS educators should make themselves aware of available study abroad programs for IS students from external program providers. Furthermore, they should identify those programs that best meet the needs of there IS students.

3. IS educators should consider offering internally developed study abroad programs that meet curriculum requirements and maximize quality of study abroad experiences.

IS majors' study abroad destination choices are not strategic. IS majors overwhelmingly believe that their industry values people with experience in Asia (particularly India, China, and Japan), yet they also overwhelmingly want to study in fun, touristpreferred destinations in Europe and Australia. Therefore, the following recommendations attempt to balance these opposing sets of destinations:

4. IS educators should become aware of the cultures/countries that knowledge of, and expertise in, will be most highly valued by potential employers of IS majors.

5. IS educators should advise IS majors who intend to study abroad to make strategic and career-oriented decisions about the location of study abroad programs.

IS majors report that parents have more influence on their study abroad decisions than friends, instructors, and advisors. Inclusion of parents, as important influencers in student choices, leads to the following recommendations:

Volume X, No. 1, 2009
6. When marketing study abroad options to IS students, IS educators should ensure that information is available that addresses parents' primary concerns about study broad programs, such as safety and security, value of program in relation to cost of program, and supervision. IS educators may even consider directly providing program information to parents.

7. Because few IS majors report that instructors and advisors have had significant influence in decision-making about studying abroad, IS educators should seek to increase their influence on students.

IS majors underestimate the cost involved in study abroad programs. Most IS students as well as business and CS students believe that short 2-3 week study abroad programs should be priced under $\$ 2,000$. In reality, most such programs in Europe and Asia are priced above $\$ 3,000$. This discrepancy between believe and reality leads to the following recommendations:

8. IS educators should seek to reduce study abroad program costs to meet the needs of IS students. A probable reason study abroad participation is so low, even though study abroad intent is so high, is that programs are considered expensive. IS educators should work closely with university study abroad offices to identify creative, cost-effective solutions for their students. IS educators should also become aware of scholarship and grant opportunities for students who study abroad.

9. IS educators should help IS students understand the significant costs associated with study abroad programs. They should also help students consider the future returns and thus help students view the study abroad experience as an investment.

IS majors express strong agreement that studying abroad and working effectively with members of other cultures is important to their careers. The fact that IS majors so strongly endorse this belief may be an indicator that internationalization efforts at the universities studied have influenced their views. In many ways, this makes the promotion of study abroad programs simpler for IS educators thus the following is recommended:

10. IS educators should focus on promotions that align with IS students' strongly positive

Issues in Information Systems 
attitudes towards working effectively with members of other cultures.

IS majors regard the impact of globalization as positive for their careers. IS student strongly believe that the impact of globalization on the domestic economy is positive. In fact, they are much more likely to endorse this view than the American public at large. Interestingly, many IS educators believe (and probably rightfully so) that the outsourcing of IT jobs as a result of globalization is one reason that many IS programs have encountered reduced enrollment in recent years. It might be natural to assume that IS students also hold these beliefs; however, this is simply not the case.

Among IS, CS, and business students, beliefs about the impact of participation in study abroad programs are the highest predictors of desire to study abroad. Beliefs about the impact of globalization on the economy and gender are not predictors of desire to study abroad. Those students who believe study abroad programs will help their careers have stronger desire to study abroad. This is intuitive; surprisingly, however, globalization beliefs are not predictors. Furthermore, the impact of gender on study abroad beliefs among IS, CS, and business students (females study abroad more so than males) has no impact on study abroad desires when accounting for other variables. The influence of income and class (i.e., underclass, upper class, graduate) is less clear. In the regression, upper class students are less likely to want to study abroad and students from upper income families were more likely to want to study abroad. Each of these findings approached significance $(p=$ $.06)$. Based on these conclusions, the following is recommended:

11. IS educators who want to influence IS students to consider study abroad programs should focus more on the direct relationship between studying abroad and career outcomes rather than the more abstract notion of how globalization impacts their careers. Generally, curriculum statements relating to international issues focus more on these abstract relationships rather than the more direct relationships between personal study abroad experiences and careers.

12. IS educators should attempt to influence IS students early in their programs, ideally when they are freshmen or at the latest when they are sophomores since interest in study abroad options appear to wane as they become upper classmen. There is another reason that IS educators should focus on influencing IS students early in their programs. As noted earlier, IS curriculums are already so full that adding classes specifically for international competencies is not feasible for most programs. Underclass students often can study abroad using the courses taken as elective credits; this becomes tougher as upper classmen. Thus, students are less likely to perceive that spending time abroad may lengthen the time until they graduate as they are merely fulfilling elective options. Similarly, some programs require internships usually in the later semesters of a program, reducing the possibility of studying abroad regardless of a student's desire.

13. IS educators should consider how to promote study abroad programs to students who come from families of lower incomes. Students from lower income families may stand to gain the most from international experiences. In part, this is an economic issue. Other possible reasons for lower income students being less likely to want to study abroad include a general lack of worldliness in lower classes as a result of income, which results in increased ethnocentrism in the group.

In terms of study abroad beliefs and desires, IS students are far more similar to business students than CS students. Since most IS programs focus on IS students becoming managers of technology, this finding should be welcomed by most IS educators. Based on this finding, the following is recommended:

14. IS educators should bundle their marketing efforts of study abroad programs with other business-related study abroad programs as they serve similar target groups.

15. IS educators who instruct CS students and are considering marketing study abroad programs to them should be aware of the different study abroad preferences and intentions of these students.

Overall, this study provides insights into the similarities and dissimilarities between IS, CS, and business students in regards to study abroad programs. Based upon the results of a study across multiple campus recommendations are offered for IS educators. In many schools there exists study aboard programs to provide opportunities early in IS majors course work for study aboard experiences. Key to 
students, their parents who influence their decisions, and their potential future employers, should be an understanding of the fit between some countries and cultures and students future career goals.

\section{REFERENCES}

1. Aggarwal, A. K., \& Rollier, B. (1994). Globalization and the information systems curriculum. ISECON' 94 Proceedings, pp. 70-74.

2. American Council on Education, Art \& Science Group, \& the College Board. 2008. College-bound students' interests in study abroad and other international learning activities. Washington, DC: Author.

3. Bailey, J. L., \& Stefaniak, G. (2002). Preparing the information technology workforce for the new millennium. ACM SIGCPR Computer Personnel, 20(4), 4-15.

4. Beard, D., Schwieger, D., \& Surendran, K. (2007). Proceedings of the 2007 ACM SIGMIS CPR Conference on Computer Personnel Research: The Global Information Technology Workforce, 179185.

5. Bhandari, R., \& Chow, P. (2008). Open doors 2008: Report on international educational exchange. New York: Institute of International Education.

6. Cardon, P. W., Marshall, B., \& Poddar, A. (2009, March 23). Tourist role typologies and study abroad preferences among management students. Comparative and International Education Society 53rd Annual Conference. Charleston, SC.

7. Ferguson, E. (2004). Impact of offshore outsourcing on CS/IS curricula. Journal of Computing Sciences in Colleges, 19(4), 6877.

8. Friedman, T. L. (2007). The world is flat: A brief history of the twenty-first century ( $3^{\text {rd }}$ ed.). New York: Picador.

9. Gorgone, J. T., Davis, G. B., Valacich, J. S., Topi, H., Feinstein, D. L., \& Longenecker, H. E., Jr. (2002). IS 2002: Model curriculum and guidelines for undergraduate degree programs in information systems. New York: ACM.

10. Granger, M. J., \& Schroeder, D. L. (1994). Enhancing existing undergraduate information systems courses with an international emphasis. Proceedings of the 1994 International Academy for Information Management Conference, pp. 75-86.
11. Joint Task Force for Computing Curricula 2005. (2005). Computing curricula 2005: The overview report covering undergraduate degree programs in computer engineering, computer science, information systems, information technology, and software engineering. Los Alamitos, CA: IEE Computer Society.

12. Noll, C. L., \& Wilkins, M. (2002). Critical skills of IS professionals: A model of curriculum development. Journal of Information Technology Education, 1(3), 143-154.

13. Rollier, B. (2001). Preparing MIS students for a global economy. Journal of Information Systems Education, 12(4), 193199.

\section{APPENDIX OF SURVEY ITEMS}

Study Abroad Desires (1, strongly disagree, to 7, strongly agree)

I want to study abroad while I am a university student.

I will be disappointed if I do not study abroad before completing my degree.

Study Abroad Attitudes and Beliefs (1, strongly disagree, to 7 , strongly agree)

Studying abroad will help me get a job.

Studying abroad will be helpful for my career.

It is important for people in my (future) industry to be able to work with members of other cultures.

I would be nervous studying abroad in places where English is not the first language.

I would prefer a study abroad program that is one semester or longer.

I would prefer a study abroad program that is part of a group from my school.

Study Abroad Preferences

For a 2- to 3-week study abroad trip, a reasonable price is: (Under $\$ 1,000 ; \$ 1,000-\$ 1,500 ; \$ 1,500$ $\$ 2,000 ; \$ 2,000-\$ 3,000 ; \$ 3,000-\$ 4,000$; Over $\$ 4,000$ ) What country would be your first choice for studying abroad?

Importance of Influential Others on Decision-Making ( 1 , strongly disagree, to 7 , strongly agree)

For a decision about studying abroad, my parent's opinions are extremely influential.
Issues in Information Systems 
For a decision about studying abroad, my friends' opinions are extremely influential.

For a decision about studying abroad, my instructors' opinions are extremely influential.

For a decision about studying abroad, my academic advisor's opinions are extremely influential.

Globalization Attitudes and Beliefs

Do you think globalization is good or bad for the following? (1=very bad; 2=bad; 3=good; 4=very good)
Consumers like you

American companies

The American economy

Your own standard of living

Your own job

Your own career

Creating jobs in America 